BUSINESS

\section{More flavour up front}

T wo young biotechnology start-ups in the United States are leading an innovative search for powerful flavour enhancers. If they succeed, biologists at the companies say, they could revolutionize food manufacture by dramatically shrinking the amounts of sugar, salt and other flavourings used by the industry.

Senomyx of La Jolla, California, and New Jersey-based Linguagen are using high-throughput techniques pioneered by the drug industry to scan thousands of compounds for their impact on human taste receptors. These poke out of tongue cells and bind to food molecules, allowing us to taste salt, sweet, bitter, sour and umami, the flavour of monosodium glutamate.

Armed with bulk screening and geneticsequence information for the receptors and their associated pathways, the companies are trying to pinpoint and refine the natural and synthetic compounds that can do the job.

${ }^{\alpha}$ The way an enhancer works is that it makes the taste receptor more efficient," says Mark Zoller, head of research at Senomyx, the larger of the two companies, which raised \$34 million in an initial public offering on NASDAQ last June. Originally called Ambryx, Senomyx was founded in 1998 by Charles Zuker, a molecular geneticist at the University of California, San Diego, who had discovered and described some of the taste receptors.

Linguagen founder Robert Margolskee, a biophysicist at the Mount Sinai School of Medicine in New York, set up his company after describing some of the other steps in the molecular pathway between food hitting the tongue and the brain recognizing a taste. Both companies really took off after the Human Genome Project made it much easier to identify the genes behind taste and express them in cells for screening.

In a typical screening process, active genes for the receptor or pathway element are inserted into mammalian cells, and the resulting transgenic cells are grown in 384-well plates. A slightly different compound is added to each well from a small-molecule library. If the com-

\section{On the up: Senomyx stock}

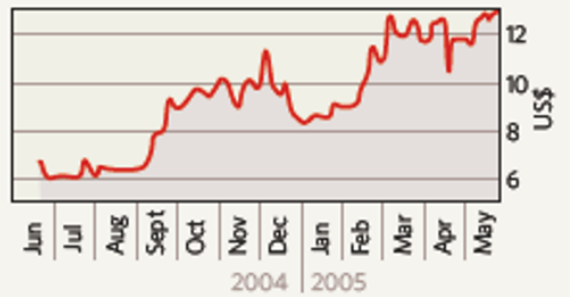

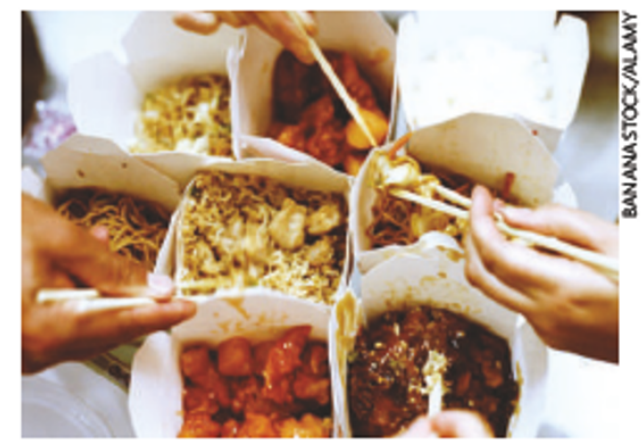

Sweet and sour: flavour enhancers would allow the foodindustry to cut back on sugar and salt.

pound binds or flirts with binding with the receptor, the activity will make the dye in the well light up. That compound will then be plucked out and its exact effect on the taste process investigated.

Because these compounds target the receptor so well, they are effective in tiny quantities small enough to qualify for an expedited safety approval process, which should take three years orless.

Senomyx, whose stock has doubled in value since last year's flotation, plans to make its money by licensing the intellectual-property rights to food companies. It already has research agreements with a brace of food giants, including Nestlé and Coca-Cola.

The two start-ups hold patents on the specific screening processes, as well as compounds they have identified as promising - advantages that could aid their survival. Investors are betting that Senomyx, at least, will turn a profit one of these days. ${ }^{\alpha}$ If things continue to go well, there is the chance that this could become a very big company, says David Weber, a stock analyst at First Albany in New York state.

Senomyx is also sitting on intellectual property relating to the olfactory receptors. Although it hasn't started an active research programme with the nose's machinery for recognizing smells, it is thinking about it.

Clint Brooks, head of research at New Yorkbased International Flavor and Fragrance, points out that this is a key consideration: the five fundamental tastes are just the base notes to flavours, which also involve many of the 300 or so olfactory receptors. He adds that while companies such as Linguagen are discovering novel, exciting molecules, these must be incorporated into the overall flavours of foods through the art and science of an experienced flavourist.

Emma Marris

\section{IN BRIEF}

BLUE CHIPS IBM has announced a tie-up with chip-makers in Taiwan and Germany to jointly research computer memory chips based on phase-change materials.

Thematerials, whose structures change from crystalline to amorphous when an electric current passes through them, have already attracted the interest of researchers at companies such as Philips in the Netherlands

(M. H. R. Lankhorst et al. Nature Mater. 4, 347-352; 2005).

Macronix of Hsinchu and the Munich-based Infineon will now join in a project involving 20 to 25 researchers working full-time at IBM's research labs in San Jose, California, and Yorktown Heights, New York.

STEM-CELL START California biotechnology firm BioDefense, which specializes in homelandsecurity work, says that it is planning an initial public offering of stock toraise funds for its stem-cell division.

The company adds that its newly founded Stem Cell Research division would specialize in the possible use of embryonic stem cells to treat acute liver disease.

Chief executive David Chin says he believes that stem cells would "allow for the development of an artificial liver". But the company has given no schedule for its stock offering.

NO GREEN LIGHT ExxonMobil's shareholders rejected a motion on climate change at the company's annual meeting on 25 May - although holders of almost $30 \%$ of the stock voted for it.

The measure would have mandated a report on how the company planned todeal with the regulations of the Kyoto Protocol in countries where it is in effect, and a study of the feasibility of reducing emissions in the UnitedStates.

This was the latest in a series of similar efforts by shareholders at major corporations (see Nature 435, 410-411; 2005). 